\title{
SH2 - Más allá de las fronteras entre países: La violencia que acompaña a las mujeres-madres migrantes centroamericanas
}

\author{
Sandra E. Herrera Ruiz \\ Dirección General de Investigación \\ Universidad de San Carlos de Guatemala
}

\section{Resumen}

$\mathrm{E}$ n la última década los estudios de género en Guatemala, han planteado no solo un incremento significativo del movimiento migratorio autónomo de las mujeres, sino que también han registrado los elementos relacionados con las subjetividades de la migración femenina. En ese marco, guatemaltecas, salvadoreñas, hondureñas y nicaragüenses, en su paso hacia Estados Unidos, que generalmente utilizan las fronteras guatemaltecas como puntos estratégicos de conexión para internalizarse en México, con diversas experiencias de vida han coincidido en ser mujeres-madres migrantes. Sus testimonios son evidencia de que mantienen una relación económica, social o emocional violenta en sus países de origen hasta que toman la decisión de romper esos vínculos. Y aunque les resulte difícil dejar todo atrás, especialmente a los hijos e hijas, deciden emprender el viaje. Ahora es posible observar los aspectos decisivos de la migración de las mujeres-madres, en un contexto público de violencia estructural y criminal, pero también en el contexto de violencia que se desarrolla en su ámbito privado. La violencia de género en mujeres-madres migrantes con una historia de maltrato, pasada o en curso, se reconoce en estos momentos como una competencia fundamental que en la discusión académica aún está en construcción. En ese sentido, es importante clarificar algunos objetivos. Uno de ellos es la vinculación que la violencia del ámbito privado tiene con el hecho migratorio y por otro lado la intensificación y "resignificación" que las mujeres hacen de esa violencia cuando cruzan de la región centroamericana.

Palabras clave: Violencia de género, subjetividades de la migración femenina, maltrato hacia las mujeres, región centroamericana

\section{Abstract}

I n the last decade gender studies in Guatemala have raised not only a significant increase in immigration autonomous women's movement, but have also recorded the elements related to the subjectivities of female migration. In this context, Guatemalan, Salvadoran, Honduran and Nicaraguan, on their way to the United States, which generally used the Guatemalan border as strategic connection points for internalized in Mexico, with diverse life experiences have agreed migrants being women-mothers. Their testimonies are evidence that a violent maintain economic, social or emotional relationship in their home countries until they decide to break those ties. And even find it difficult to leave everything behind, especially children, decide to undertake the journey. It is now possible to observe the critical aspects of migration of women-mothers, in a public context of structural and criminal violence, but also in the context of violence that takes place in the private sphere. Gender-based violence in migrant women-mothers with a history of abuse, past or ongoing right now is recognized as a fundamental competence in academic discussion is still under construction. In that sense, it is important to clarify some objetives. One of them is linking violence with the private sphere, and on the other hand the "resignification" of the violence that women make when they cross in Central America.

Keywords: Gender violence, subjectivities of female migration, mistreatment of women, Central America 